\title{
SPS-BANSHO UNTUK MENINGKATKAN AKTIVITAS BELAJAR MATEMATIKA PESERTA DIDIK SMPN 18 TANGERANG
}

\author{
Dyah Sinto Rini \\ SMPN 18 Tangerang, Perum Poris Indah Blok G, Cipondoh, Kota Tangerang; \\ dyahsintorini@gmail.com
}

\begin{abstract}
Abstrak. Artikel ini adalah best practice yang telah dilaksanakan dengan menerapkan model pembelajaran SPS-Bansho (Structured Problem Solving using Bansho) di SMPN 18 Tangerang. Best practice ini telah berhasil meningkatkan aktivitas belajar matematika peserta didik selama proses pembelajaran berlangsung. Lembar observasi digunakan sebagai panduan dalam mengamati aktivitas belajar matematika peserta didik selama proses pembelajaran. Hasil penerapan model pembelajaran ini menunjukkan bahwa semua indikator aktivitas belajar matematika peserta didik meningkat selama proses pembelajaran. Peserta didik menjadi lebih berani mengajukan pertanyaan pada waktu diskusi kelompok maupun diskusi kelas, mampu memberikan respon atas pendapat temannya dengan baik, mau berpartisipasi dalam kelompok, bersedia membantu teman dalam menyelesaikan tugas, mau mencoba melakukan presentasi hasil kerja kelompok di depan kelas, dan dapat dengan mudah menyusun rangkuman materi yang telah dipelajari.
\end{abstract}

Kata Kunci. SPS-Bansho, . aktivitas belajar, matematika

\section{The Learning Model of SPS-Bansho to Improve Student Mathematics Learning Activities at SMPN 18 Tangerang}

\begin{abstract}
This article is a best practice implemented by applying the learning model of SPS-Bansho (Structured Problem Solving using Bansho) at SMPN 18 Tangerang. This best practice has succeeded in increasing students' mathematics learning activities during the learning process. The observation sheet was used to observe the students' mathematics learning activities. All indicators of students' mathematics learning activities were observed during the learning process. Students were challenged more to ask questions during a group or class discussions. They were able to respond to their friends' opinions well, participate in groups, and help friends in completing assignments. Students presented their work in front of the class, and they could summarize the material they have learned.
\end{abstract}

Keyword. SPS-Bansho, learning activities, mathematics

\section{Pendahuluan}

Berdasarkan pengalaman penulis dalam mengajar mata pelajaran matematika serta berdasarkan hasil wawancara dengan beberapa peserta didik di SMPN 18 Tangerang, tempat penulis mengajar, penulis menemukan bahwa sebagian besar peserta didik tidak menyukai mata pelajaran matematika. Peserta didik menganggap matematika adalah pelajaran yang paling sulit. Pada pelaksanaan pembelajaran, sering dijumpai peserta 
didik yang tidak memberikan perhatian penuh terhadap penjelasan guru di depan kelas, mengobrol dengan temannya atau hanya menyalin catatan dan hasil pekerjaan milik temannya. Peserta didik yang kurang menyukai pelajaran matematika menyebabkan kecemasan dan tingkat kesulitan yang tinggi dalam memahami materi yang dipelajari dan berdampak pada rendahnya prestasi belajar matematika. Slameto (2010) mengemukakan bahwa peserta didik dengan tingkat kecemasan yang tinggi tidak bisa berprestasi sebaik peserta didik dengan kecemasan yang rendah.

Penulis juga mengamati bahwa pada pelaksanaan pembelajaran matematika di SMPN 18 Tangerang, guru kurang bervariasi dalam menggunakan metode, model, media dan pendekatan atau strategi pembelajaran. Guru lebih sering menggunakan metode pembelajaran konvensional yang berpusat pada guru (teacher centered learning) sehingga tidak memberikan kesempatan kepada peserta didik untuk mengembangkan ide kreatif mereka agar memperoleh pemahaman yang lebih baik tentang konsep matematika yang sedang dipelajari. Hal ini membuat peserta didik menjadi lebih pasif dalam mengikuti proses pembelajaran. Guru menjadikan siswa sebagai obyek, bukan subyek. Pembelajaran seperti ini membatasi gerak ruang berpikir peserta didik karena semua yang diberikan guru harus diterima peserta didik, karena guru merupakan sumber pengetahuan (Murwani, 2006). Pendekatan teacher centered learning menurut Harto (2012) merupakan proses pembelajaran yang berpusat pada guru, di mana guru menyampaikan materi dan hanya akan membuat guru semakin pandai. Peserta didik hanya memiliki pengalaman mendengar ceramah saja. Sistem teacher centered learning menghasilkan peserta didik yang kurang mampu mengapresiasi ilmu pengetahuan, takut berpendapat, tidak berani mencoba yang akhirnya cenderung menjadi pelajar yang pasif dan kurang kreativitas.

Dale (1969) dalam buku berjudul Audioisual Methods in Teaching menganggap bahwa kerucut merupakan analogi visual untuk menunjukkan perkembangan belajar. Kerucut Edgar Dale adalah representasi visual tentang bagaimana manusia mendapatkan pemahaman dari jenis pengalaman (experience) yang berbeda. Edgar Dale mengemukakan tentang cara belajar dan tingkat ingatan hasil pembelajaran yaitu hanya mengingat sebesar $10 \%$ jika belajar dengan cara membaca, $20 \%$ jika belajar dengan cara mendengar, 30\% jika belajar dengan cara melihat gambar atau video, 50\% jika belajar dengan cara terlibat dalam diskusi, $70 \%$ jika belajar dengan cara menyajikan atau presentasi dan $90 \%$ jika belajar dengan cara bermain peran, melakukan simulasi atau mengerjakan hal yang nyata. Jika pembelajaran berpusat pada guru (teacher centered learning) dan peserta didik hanya mendengarkan penjelasan guru, maka informasi yang dapat diingat oleh peserta didik hanya $20 \%$.

Kondisi peserta didik yang pasif dalam pembelajaran mengakibatkan peserta didik jarang sekali mengajukan pertanyaan, apalagi mengungkapkan pendapat atau pun mempresentasikan hasil pekerjaannya di depan kelas. Keaktifan belajar peserta didik yang rendah menyebabkan tingkat pemahaman konsep matematika kurang sehingga prestasi belajar matematika juga rendah. Keaktifan peserta didik sangat diperlukan, peserta didik yang seharusnya aktif karena peserta didik adalah subyek didik yang melaksanakan belajar (Usman, 2009). Peserta didik yang aktif selama proses 
pembelajaran membuat mereka dapat menemukan pengetahuan, informasi atau keterampilan karena mereka memperoleh pengalaman secara langsung. Apabila peserta didik belajar dengan aktif mereka mudah memahami materi pelajaran. Peserta didik dapat mengembangkan pola pikir kreatif untuk mencoba memecahkan masalah-masalah yang ditemui dalam belajar. Seorang peserta didik yang aktif juga dapat dilihat dari peserta didik mengkomunikasikan hasil pemikirannya, mudah mengemukakan pendapat, bisa berdiskusi dengan teman serta mampu mempresentasikan hasil karyanya.

Aktivitas pembelajaran peserta didik adalah semua kegiatan yang dilakukan di dalam kelas pada saat proses pembelajaran yang menghasilkan suatu perilaku yang mempengaruhi hasil belajar peserta didik. Peserta didik dituntut untuk aktif dalam semua proses pembelajaran termasuk dalam pembelajaran matematika. Dibutuhkan suatu perencanaan yang baik agar pembelajaran matematika menjadi lebih bermakna serta dapat meningkatkan aktivitas belajar peserta didik untuk berpartisipasi aktif dalam proses pembelajaran. Sebagai guru matematika di SMPN 18 Tangerang, penulis selalu berupaya menemukan cara untuk meningkatkan aktivitas belajar peserta didik agar dapat mengalami, mencari dan menemukan sendiri pemahaman konsep matematika. Salah satu model pembelajaran matematika yang dapat dilaksanakan adalah Structured Problem Solving, yang selanjutnya disingkat SPS, suatu pendekatan pemecahan masalah terstruktur.

Penerapan model pembelajaran SPS pada pembelajaran matematika di SMPN 18 Tangerang penulis lengkapi dengan langkah-langkah pembelajarna yang terorganisir dengan baik, salah satunya mengatur penggunaan papan tulis secara efektif yang disebut bansho. Pengaturan papan tulis diperlukan untuk menyajikan langkah-langkah model pembelajaran SPS di kelas dengan baik. Penerapan model pembelajaran SPS dan pengaturan papan tulis secara efektif (bansho) penulis sebut sebagai SPS-Bansho, yaitu model pembelajaran Structured Problem Solving (SPS) sebagai suatu pendekatan pemecahan masalah terstruktur dengan menggunakan pengorganisasian papan tulis (Bansho). Menurut Yoshida (2002) tujuan bansho adalah untuk mengorganisasikan dan mencatat hasil pemikiran matematika dari seluruh peserta didik pada papan tulis besar. Papan tulis bansho ini merupakan catatan tertulis dari seluruh peserta didik di mana ideide, ekspresi, strategi dan solusi matematika dituangkan di sini. Bansho dapat membangun koherensi dan memberikan referensi poin-poin penting dalam pembelajaran matematika. Bansho juga dapat membantu peserta didik untuk melihat ringkasan materi pembelajaran, memberikan kesempatan kepada peserta didik untuk berpartisipasi aktif selama pembelajaran serta dapat menjadi tempat berdiskusi tentang pemikiran matematika yang beragam.

Artikel ini merupakan karya tulis best practice penerapan model pembelajaran SPSBasho. Best practice ini mengupas tentang pelaksanaan pembelajaran dengan SPSBansho untuk meningkatkan aktivitas belajar matematika peserta didik SMPN 18 Tangerang. Rumusan permasalahan pada best practice ini adalah: (1) Bagaimana gambaran penerapan model pembelajaran SPS-Bansho di SMPN 18 Tangerang? (2) Bagaimana hasil atau dampak dari penerapan model pembelajaran SPS-Bansho di SMPN 
18 Tangerang? Best practice ini diharapkan dapat memberikan inspirasi dan referensi bagi para pembaca dalam upaya untuk meningkatkan kualitas pembelajaran matematika, khususnya terkait dengan peningkatan ativitas belajar peserta didik.

\section{Kajian Teori}

\subsection{Aktivitas Belajar}

Arti kata aktivitas menurut kamus besar bahasa Indonesia adalah keaktifan atau kegiatan (https://kbbi.web.id/aktivitas, 2017). Aktivitas merupakan prinsip atau asas yang sangat penting dalam interaksi belajar mengajar (Djamarah dan Bahri, 2010). Aktivitas belajar peserta didik adalah serangkaian kegiatan peserta didik baik fisik maupun mental yang saling berkaitan selama proses pembelajaran sehingga tercipta pembelajaran yang optimal (Sardiman, 2011). Berdasarkan pendapat di atas, dapat disimpulkan bahwa aktivitas belajar merupakan kegiatan atau tindakan baik fisik maupun mental yang dilakukan oleh peserta didik untuk membangun pengetahuan dan keterampilan dalam diri peserta didik pada proses pembelajaran. Proses pembelajaran akan bermakna, apabila peserta didik terlibat secara aktif dalam proses pembelajaran.

Berbagai aktivitas belajar sangat penting dan berkaitan karena dengan proses belajar di lakukan sendiri oleh peserta didik, artinya belajar yang baik didapat dari pengalaman langsung dalam pembelajaran. Tugas guru membimbing dan menyediakan kondisi agar peserta didik dapat mengembangkan bakat dan potensinya. Peserta didik yang harus beraktivitas, berbuat dan aktif sendiri secara individual maupun kelompok. Peserta didik yang belajar aktif menunjukkan intelektual dan emosional yang tinggi dalam proses belajar. Peserta didik dapat berdiskusi, mengemukakan pendapat dan idenya, dan mampu melakukan eksplorasi terhadap materi yang sedang dipelajari serta menafsirkan hasilnya secara bersama-sama dalam kelompok.

\subsection{Model Pembelajaran SPS-Bansho}

Suatu pemecahan masalah (problem soving) dipandang sebagai aktivitas kognitif yang paling penting dalam konteks sehari-hari, terutama dalam proses pembelajaran (Jonassen, 2000). Semakin banyak perhatian diberikan kepada peserta didik dalam mengembangkan keterampilan pemecahan masalah. Peserta didik diharapkan dapat menggunakan prinsip yang tepat untuk membuat keputusan dalam kegiatan pemecahan masalah (Xie, 2006). Berdasarkan pendapat di atas, maka pemecahan masalah merupakan proses penting dalam meningkatkan pemahaman, pengetahuan, sikap dan keterampilan berpikir peserta didik. Guru memotivasi peserta didik untuk mengeluarkan pendapat sesuai dengan kemampuan yang dimiliki, guru menghargai pendapat peserta didik dan kemudian mengarahkan peserta didik kepada pemecahan masalah yang benar.

Structured Problem Solving (SPS) adalah model pembelajaran problem solving yang dikembangkan Leong, Teoh dan Warabhorn, pengajar dari SEAMEO RECSAM, Malaysia, dengan enam urutan langkah terstruktur (Leong, Teoh dan Warabhorn, 2012). Langkah 
pertama adalah "reviewing the previous lesson" atau mengulas materi sebelumnya. Sangat penting untuk mengetahui pengetahuan awal peserta didik sebagai pengetahuan prasyarat untuk mempelajari materi baru. Langkah kedua adalah "presenting the problem for the day" yaitu menyajikan permasalahan matematika yang kontekstual dan menantang. Guru harus memastikan bahwa peserta didik memahami permasalahan dengan baik. Langkah ketiga adalah "students working on their own (individually or in groups)" yang berarti peserta didik bekerja untuk menyelesaikan permasalahan dengan pengetahuan matematika yang telah mereka miliki, baik secara individu, berpasangan atau dalam kelompok kecil. Guru mencermati ide-ide smart yang mungkin dimiliki peserta didik dalam memecahkan permasalahan yang diberikan. Selanjutnya langkah keempat yaitu "whole-class discussion" atau diskusi kelas. Pada tahap ini, peserta didik mempresentasikan pemecahan masalah kemudian bersama-sama membandingkan dan menganalisis perbedaan atau persamaan penyelesaian permasalahan yang diberikan. Langkah kelima adalah "summing up (highlighting and summarising the main point)", yaitu peserta didik menyimpulkan hasil diskusi. Guru membimbing peserta didik untuk membuat kesimpulan tentang pengetahuan baru, serta melakukan refleksi atas pembelajaran hari ini. Langkah keenam yaitu "exercises or extension" atau ekstensi yaitu dengan memberikan latihan penguatan.

Berdasarkan langkah-langkah penerapan Structured Problem Solving, guru dituntut menyajikan dan mempromosikan permasalahan matematika yang kontekstual, menantang dan menghasilkan berbagai cara penyelesaian yang dapat dibandingkan dan dianalisis untuk mengembangkan keterampilan berpikir peserta didik. Dengan SPS, peserta didik diharapkan dapat memecahkan permasalahan matematika menggunakan pengetahuan matematika yang telah mereka miliki, berpikir secara mendalam dan kritis sehingga dapat menghubungkan pengetahuan yang telah dipelajari sebelumnya dengan konsep baru yang sedang dipelajari.

\subsection{Bansho}

Rangkaian langkah dalam penerapan pembelajaran Structured Problem Solving (SPS) harus dapat terorganisir dengan baik sehingga pembelajaran menjadi lebih bermakna dan bisa mencapai tujuannya. Cara yang sudah sering dilakukan oleh guru-guru di Jepang adalah dengan menggunakan bansho. Kajander, Holm \& Chernoff menyatakan bahwa bansho merupakan cara mengorganisasi papan tulis sebagai strategi pembelajaran matematika agar dapat menumbuhkan pemikiran matematis peserta didik dan melatih pengetahuan kolektif peserta didik melalui diskusi yang terkoordinasi untuk menemukan solusi permasalahan pembelajaran.

Bansho adalah istilah yang dikembangkan oleh komunitas pendidikan di Jepang untuk pengorganisasian papan tulis (blackboard atau whiteboard) dalam pembelajaran di kelas. Arti harfiah dari kata 'board writing' yang kemudian diistilahkan bansho oleh guruguru matematika di Jepang diterapkan dengan mengatur penggunaan papan tulis secara efektif untuk menyajikan langkah-langkah pembelajaran di kelas. Hal ini dimaksudkan agar seluruh peserta didik mendapat kesempatan untuk melihat, membaca dan memahami pemikiran, hasil diskusi atau hasil kerja berkaitan dengan materi yang 
sedang dipelajari. Kegunaan bansho adalah menyimpan catatan pelajaran, membantu peserta didik melihat hubungan antar bagian serta perkembangan materi yang sedang dipelajari, membandingkan, melihat perbedaan, dan mendiskusikan gagasan yang disajikan peserta didik, mengatur pemikiran dan penemuan ide-ide baru peserta didik, serta menumbuhkan keterampilan peserta didik membuat catatan yang terorganisir. (http://www.edu.gov.on.ca/eng/literacynumeracy/inspire/research/CBS_bansho.pdf , 2017).

Gambar berikut ini menampilkan contoh tampilan skema bansho.

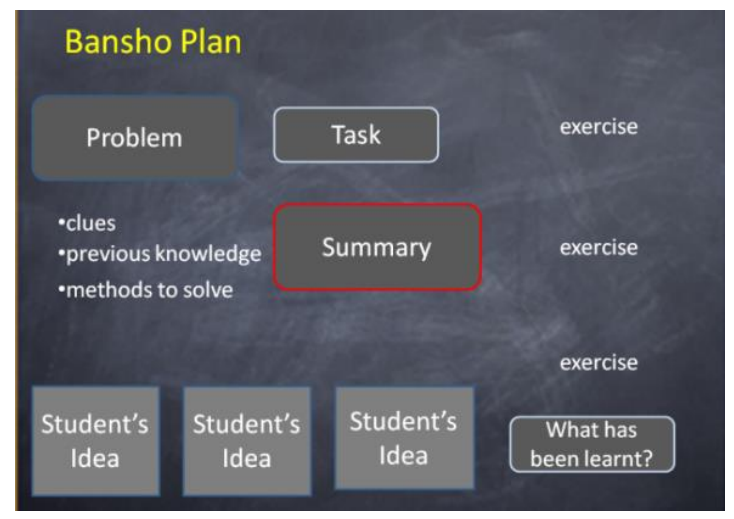

Gambar 1. Bansho (Leong, C. K., Teoh, B. T. \& Warabhorn, P, 2012)

SPS-Bansho adalah singkatan istilah yang selanjutnya penulis gunakan untuk merepresentasikan model pembelajaran Structured Problem Solving (SPS) dengan menggunakan pengorganisasian papan tulis (Bansho). Bansho sebagai pengorganisasian papan tulis memuat bagian-bagian yang dikaitkan dengan langkah-langkah pemecahan masalah terstruktur dari Structured Problem Solving (SPS). Pada Gambar 1 dapat dilihat contoh penempatan bagian-bagian untuk 6 langkah tersebut. Langkah kesatu ditempatkan pada bagian materi prasyarat (clues, previous knowledge, methods to solve). Langkah kedua, permasalahan kontekstual, diletakkan pada bagian "Problem" dan pertanyaan atau tugas pada bagian "Task". Langkah ketiga dan keempat berarti harus ada tempat untuk menampilkan hasil kerja kelompok yaitu pada bagian pemikiran atau hasil kerja peserta didik (Student's Idea). Bagian ini disediakan paling banyak agar dapat menampung ide-ide atau pemikiran peserta didik dalam menyelesaikan permasalahan yang diberikan. Langkah kelima, rangkuman materi diletakkan pada bagian kesimpulan (Summary) dan refleksi diletakkan pada bagian "What has been learnt?" (apa yang sudah dipelajari). Langkah keenam menempati bagian "exercise" (latihan). Selanjutnya guru bersama peserta didik dapat mengembangkan sendiri skema bansho beserta bagian-bagiannya.

Pembelajaran yang dilaksanakan dengan menggunakan bansho memungkinkan peserta didik melihat pemikiran mereka sendiri dalam konteks pemikiran serupa dari peserta didik lain. Peserta didik diharapkan untuk mengikuti dan mampu menggambarkan semua hasil pekerjaan baik pekerjaan mereka sendiri (individu atau kelompok) atau milik temannya. Mereka mendengarkan penjelasan atau strategi penyelesaian masalah 
dari peserta didik lain. Semua peserta didik memiliki kesempatan untuk belajar lebih banyak dalam mengembangkan dan memperjelas pemahaman mereka tentang konsep materi yang sedang dipelajari. Bansho melibatkan guru dalam memeriksa pekerjaan peserta didik, mengatur dan menampilkan anotasi serta mendiskusikan penyelesaian permasalahan.

Beberapa penelitian tentang penggunaan bansho sudah dilakukan dan terbukti dapat meningkatkan aktivitas belajar dan menumbuhkan kreativitas peserta didik. Penelitian oleh Rahmat (2018) berjudul "Menumbuhkan Kreativitas Siswa Dengan Pembelajaran Menggunakan Bansho" menunjukkan bahwa kreativitas peserta didik dapat tumbuh dengan memberikan masalah yang diselesaikan dengan cara yang menurut peserta didik benar dan sesama peserta didik dapat membandingkan penyelesaian mereka dengan teman mereka karena difasilitasi oleh bansho. Penelitian lain berjudul "Meningkatkan Kemampuan Berpikir Kreatif Matematis Siswa SMP Negeri 1 Pagaden Melalui Model Pembelajaran Bansho" menunjukkan bahwa berpikir kreatif matematika siswa SMP yang mendapat pembelajaran matematika dengan menggunakan bansho lebih baik daripada peserta didik yang mendapatkan pembelajaran matematika tanpa menggunakan bansho. Peserta didik memandang bahwa pembelajaran matematika menggunakan bansho terlaksana lebih baik dibandingkan dengan pembelajaran matematika tanpa menggunakan bansho (Nugraha, 2011). Penelitian lain dilakukan Takahashi pada tahun 2006, hasilnya menunjukkan bahwa guru di Jepang menggunakan papan tulis (bansho) sebagai alat bantu visual agar peserta didik dapat berpartisipasi dalam diskusi di kelas. Aktivitas peserta didik menjadi lebih meningkat, karena itu di Jepang dikembangkan keterampilan guru dalam menggunakan bansho secara efektif. Rencana penggunaan bansho merupakan komponen utama dari perencanaan pembelajaran dan merupakan keterampilan penting bagi guru untuk dikembangkan. Hasil penelitian ini mendorong penulis melaksanakan best practice dengan menerapkan model pembelajaran SPS-Bansho untuk meningkatkan aktivitas belajar matematika peserta didik di sekolah penulis.

\section{Strategi dan Implementasi}

\subsection{Alasan Strategi Pemecahan Masalah yang Dipilih}

Pemilihan pemecahan masalah pembelajaran matematika di SMPN 18 Tangerang dengan menerapkan model pembelajaran SPS-Bansho (Structured Problem Solving using Bansho) dilandasi pemikiran bahwa pembelajaran matematika harus fokus pada proses yang dapat mendorong peserta didik agar selalu aktif selama proses pembelajaran berlangsung. Model pembelajaran SPS-Bansho menyajikan enam urutan langkah terstruktur yang memungkinkan peserta didik untuk berpartisipasi secara aktif pada setiap langkahnya. Permasalahan matematika kontekstual yang menantang memfasilitasi peserta didik memunculkan solusi cerdas pada saat diskusi kelompok maupun diskusi kelas. Peserta didik juga dituntut untuk selalu aktif dalam pengaturan penggunaan papan tulis atau bansho. Peserta didik dapat menggunakan bansho untuk mengamati permasalahan kontekstual yang diberikan serta apa saja pengetahuan prasyarat yang dapat digunakan untuk menyelesaikan permasalahan. Hasil kerja 
kelompok harus ditempelkan pada bansho, demikian juga dengan kesimpulan materi yang sedang dipelajari serta tugas yang diberikan. Semua peserta didik dapat berdiskusi dengan memperhatikan bansho dan bagian-bagiannya. Guru mengoptimalkan penerapan model pembelajaran SPS-Bansho untuk meningkatkan aktivitas peserta didik pada proses pembelajaran matematika.

\subsection{Strategi Pemecahan Masalah}

\subsubsection{Menyusun Rencana Pelaksanaan Pembelajaran (RPP)}

Best practice ini penulis laksanakan di kelas VII.3 semester genap tahun pelajaran 2018/2019 pada kompetensi dasar (3.11) Mengaitkan rumus keliling dan luas untuk berbagai jenis segiempat (persegi, persegipanjang, belahketupat, jajargenjang, trapesium, dan layang-layang) dan segitiga, dan (4.11) Menyelesaikan masalah kontekstual yang berkaitan dengan luas dan keliling segiempat (persegi, persegipanjang, belahketupat, jajargenjang, trapesium, dan layang-layang) dan segitiga. Best practice ini dilaksanakan pada pembelajaran materi 'Luas trapesium'.

Dalam pelaksanaannya, penulis melengkapi rencana pelaksanaan pembelajaran (RPP) dengan lembar kerja. Penulis mengkhususkan pembelajaran untuk mencapai tujuan pembelajaran "Menentukan rumus luas trapesium berdasarkan luas poligon (banyak sudut)". Penulis mengarahkan peserta didik agar tidak menggunakan rumus luas trapesium secara langsung, tetapi peserta didik diarahkan untuk menemukan sendiri rumus luas trapesium dengan membentuk kembali (reshaping) trapesium menjadi poligon lain yang telah diketahui sebelumnya, kemudian peserta didik diharapkan dapat menurunkan rumus luas trapesium berdasarkan rumus luas poligon. Penulis menyusun lembar kerja untuk mengarahkan peserta didik dalam menemukan sendiri konsep luas trapesium. Peserta didik diminta untuk menemukan luas suatu daerah berbentuk trapesium berdasarkan rumus-rumus luas daerah segiempat atau segitiga yang sudah diketahui sebelumnya (sebagai materi prasyarat), jadi tidak menggunakan rumus luas trapesium secara langsung. Selanjutnya peserta didik diarahkan untuk menemukan sendiri rumus luas trapesium.

\subsubsection{Menyusun Lembar Observasi}

Untuk mengetahui aktivitas belajar peserta didik selama proses pembelajaran, penulis menggunakan lembar observasi yang memuat serangkaian indikator yang digunakan sebagai pedoman untuk mengamati aktivitas belajar peserta didik. Penulis menentukan indikator aktivitas belajar yang diamati yaitu: (1) mengajukan pertanyaan; (2) menanggapi/ memberikan respon dengan baik pendapat teman; (3) mampu berpartisipasi dengan baik di dalam kelompok; (4) bersedia membantu teman dalam menyelesaikan tugas; (5) melakukan presentasi di depan kelas; (6) membuat catatan/ rangkuman materi yang dipelajari. Penulis menyusun lembar observasi untuk mengamati aktivitas semua peserta didik selama proses pembelajaran, dan untuk memudahkan dalam observasi, penulis melakukannya untuk setiap kelompok. Lembar 
observasi hanya memuat nama peserta didik dalam setiap kelompo dan indikator aktivitas belajar. Guru memberi checklist pada kolom indikator yang terpenuhi.

\subsubsection{Menyiapkan Lembar Refleksi}

Refleksi adalah sebuah proses mereviu pengalaman dengan cara mendeskripsikan, menganalisis atau mengevaluasi proses pembelajaran yang telah dilakukan. Lembar refleksi ini diisi oleh peserta didik untuk mengetahui respon atau tanggapan peserta didik terhadap pelaksanaan pembelajaran. Penulis menyiapkan selembar kertas yang hanya bertuliskan "Lembar Refleksi" dengan baris untuk mengisi nama dan kelas. Kertas tersebut kosong, karena penulis memberikan kebebasan kepada peserta didik untuk mengungkapkan hal-hal apa saja yang telah mereka alami, peroleh dan rasakan selama mengikuti pembelajaran. Peserta didik dapat menyatakannya dengan kata-kata ataupun dengan gambar-gambar (emoticon) yang mewakili perasaan mereka selama mengikuti pembelajaran.

\subsection{Implementasi}

Sebelum pelaksanaan pembelajaran, peserta didik sudah dibagi menjadi beberapa kelompok yang beranggotakan 4 sampai 5 orang. Peserta didik juga sudah diinformasikan tentang model pembelajaran SPS-Bansho. Peserta didik sudah mengetahui langkah-langkah Structured Problem Solving (SPS) dan penggunaan bansho sebagai pengorganisasian penggunaan papan tulis. Peserta didik juga sudah diberi penjelasan tentang pembagian papan tulis yang akan digunakan untuk menuliskan beberapa hal penting berikut: materi prasyarat, tugas atau permasalahan yang harus diselesaikan, hasil pekerjaan peserta didik, rangkuman materi, latihan serta refleksi.

Selama proses pembelajaran, guru mengoptimalkan terlaksananya langkah-langkah pemecahan masalah terstruktur (Structured Problem Solving). Dimulai dengan mengulas materi prasyarat dan memberikan permasalahan kontekstual dan menantang, guru sudah melibatkan peserta didik untuk selalu berpartisipasi secara aktif. Guru juga harus memastikan bahwa semua peserta didik memahami permasalahan yang diberikan.

Permasalahan pada lembar kerja diberikan untuk diselesaikan peserta didik secara berkelompok. Permasalahan yang diberikan adalah permasalahan kontekstual seharihari yang terjadi di sekitar kita. Penulis mengangkat permasalahan tentang bagaimana menghitung biaya untuk membeli kaca jendela berbentuk trapesium jika diketahui ukuran jendela dan harga kaca. 


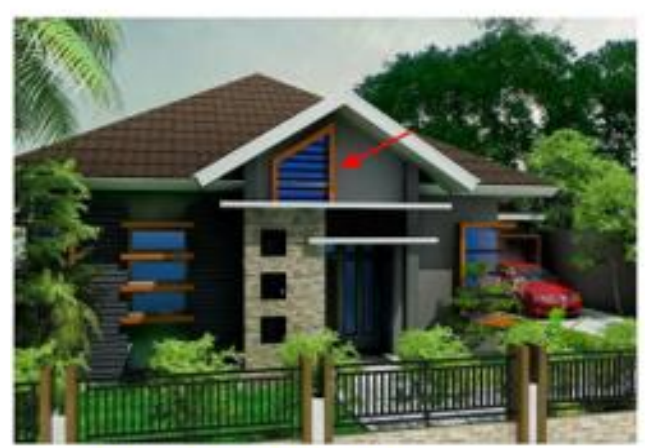

desaindenahrumahcom

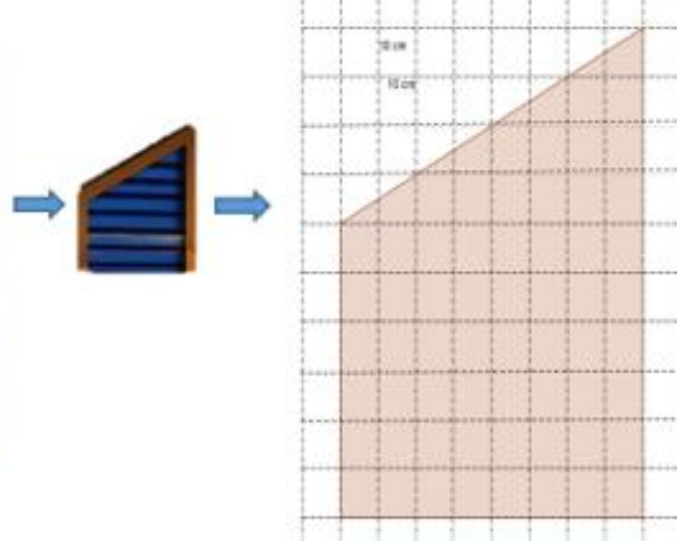

Gambar 2. Contoh konteks permasalahan pada lembar kerja

Pada lembar kerja disajikan gambar rumah milik Pak Ali di mana salah satu jendelanya yang berbentuk trapesium dilapisi kaca. Pak Ali ingin mengganti kaca jendela tersebut. Pada gambar berikutnya, bagian jendela diperjelas dengan ukurannya. Harga kaca diketahui yaitu Rp200.000,00 per meter persegi, peserta didik diminta menghitung banyak uang yang harus disediakan Pak Ali untuk membeli kaca agar pas digunakan untuk melapisi jendela tersebut.

Bersama peserta didik, guru membahas permasalahan pada lembar kerja. Setelah peserta didik memahami permasalahan yang diberikan, mereka bekerja secara berkelompok untuk menyelesaikan permasalahan tersebut.
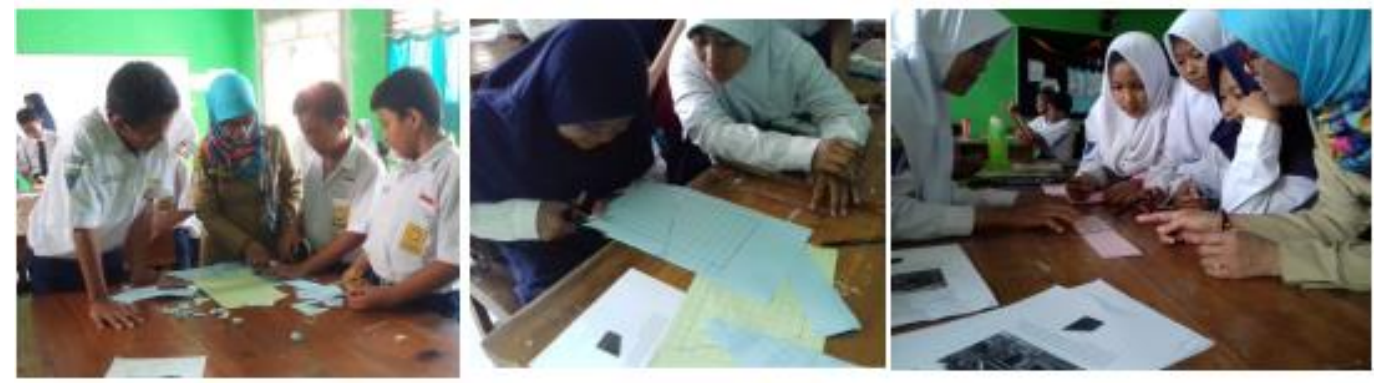

Gambar 3. Peserta didik aktif bekerja dan berdiskusi kelompok

Pada gambar 3 terlihat bahwa peserta didik aktif bekerja dalam kelompok. Mereka mengamati gambar, menggunting trapesium, mencoba membentuknya menjadi bangun datar lain, menempelkan dan mencoba menghitung luasnya hingga akhirnya mereka harus menghitung biaya yang diperlukan.

Pada waktu diskusi kelompok, guru bertindak sebagai fasilitator sambil terus membimbing peserta didik yang mengalami kesulitan. Guru juga mengamati ide-ide cerdas yang dikemukakan para peserta didik dalam menyelesaikan permasalahan. Guru mengingatkan agar peserta didik saling membantu sesama anggota kelompok hingga semua memahami permasalahan maupun cara penyelesaian sebagai jawaban setiap 
kelompok. Hasil kerja kelompok ditempelkan pada bansho disertai nama kelompok masing-masing.

Peserta didik diberi kesempatan untuk aktif mempresentasikan hasil kerja kelompok di depan kelas dengan memanfaatkan bansho. Guru membimbing dan mengingatkan peserta didik agar ikut aktif baik dalam menjawab pertanyaan maupun menanggapi atau memberikan respon atas jawaban temannya. Peserta didik juga aktif menempelkan atau menuliskan kesimpulan materi yang sedang dipelajari pada bansho. Guru mengoptimalkan penggunaan bansho untuk memberi penguatan berupa latihan soal. Dengan bansho peserta didik dapat mengamati dan mempelajari kembali konsep materi yang sudah dipelajari.

\section{Hasil dan Pembahasan}

\subsection{Hasil dan Dampak yang Dicapai}

Proses pembelajaran pada best practice ini dilaksanakan sesuai dengan rencana pelaksanaan pembelajaran (RPP) yang telah disusun sebelumnya. Keenam indikator yang dinilai pada lembar observasi aktivitas belajar peserta didik teramati atau muncul selama proses pembelajaran berlangsung. Pembelajaran matematika dengan menerapkan model pembelajaran SPS-Bansho di SMPN 18 Tangerang memberikan hasil atau dampak yang baik bagi semua peserta didik.

Sebelum penerapan model pembelajaran SPS-Bansho, peserta didik merasa malu dan tidak mau bertanya meskipun mereka mengalami kesulitan. Setelah pelaksanaan pembelajaran dengan SPS-Bansho, peserta didik mau diajak bekerja bersama secara kelompok dan berani mengajukan pertanyaan baik pada waktu diskusi kelompok maupun diskusi kelas. Peserta didik yang sebelumnya pasif menjawab pertanyaan atau merespon pendapat temannya, setelah pelaksanaan pembelajaran SPS-Bansho menjadi terlatih dalam memberikan respon tentang pendapat temannya dengan baik. Mereka mau mengacungkan tangan lebih dulu, bergantian berbicara, pun saling menghargai perbedaan pendapat. Pada pelaksanaan pembelajaran dengan SPS-Bansho, dengan bimbingan guru, semua peserta didik mampu berpartisipasi dengan baik dan aktif dalam diskusi kelompok. Didukung oleh guru yang selalu mengingatkan dan membimbing agar semua anggota kelompok dipastikan dapat memahami permasalahan maupun penyelesaiannya, karakter peserta didik menjadi lebih baik. Sebelum penerapan model pembelajaran SPS-Bansho, peserta didik cenderung belajar secara individual, namun selama pelaksanaan pembelajaran dengan SPS-Bansho, peserta didik saling membantu sesama anggota kelompoknya dalam menyelesaikan permasalahan dan tugas yang diberikan. Sebelum penerapan model pembelajaran SPS-Bansho, peserta didik tidak terbiasa melakukan presentasi di depan kelas. Selama dan setelah pelaksanaan best practice, cukup banyak peserta didik yang akhirnya mau mencoba presentasi di depan kelas, Guru selalu mengingatkan kepada semua peserta didik agar saling menghormati dan menghargai pendapat temannya terutama pada waktu diskusi kelas. Guru juga mendampingi peserta didik yang mencoba mempresentasikan hasil kerja kelompoknya. Meskipun ada yang masih merasa grogi dan takut, pada akhirnya mereka merasa senang 
dan lebih percaya diri setelah berhasil melakukan presentasi di depan kelas. Sebelum pelaksanaan pembelajaran dengan SPS-Bansho, peserta didik sering tertinggal dalam mencatat materi yang dipelajari, namun dengan menggunakan bansho, semua peserta didik dapat mengamati dan mempelajari kembali permasalahan dan penyelesaian yang bervariasi sehingga dapat memperjelas pemahaman mereka tentang konsep materi yang sedang dipelajari. Dengan melihat tampilan bansho yang mengalir dari awal hingga akhir proses pembelajaran, peserta didik dapat dengan mudah menyusun rangkuman materi yang telah dipelajari.

Dari catatan refleksi yang dibuat oleh peserta didik, sebagian besar menyatakan senang belajar matematika dengan model pembelajaran SPS-Bansho, senang belajar berkelompok karena bisa bertanya dan diajari temannya, merasa lebih percaya diri karena bisa melakukan presentasi di depan kelas serta menyatakan bahwa semua pekerjaan dan catatan terekam rapi dan lengkap pada bansho.

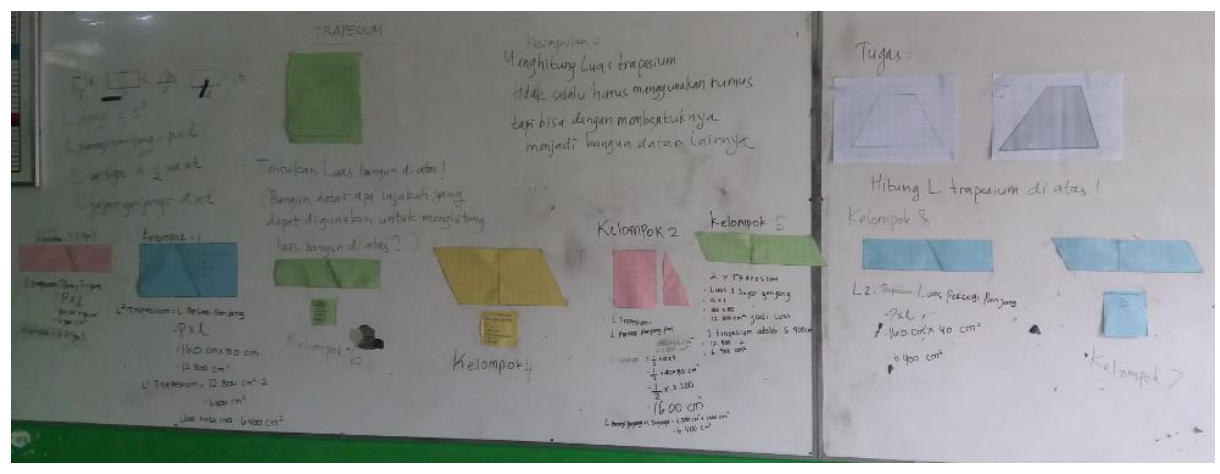

Gambar 4. Papan tulis pada pembelajaran SPS-Bansho

Bansho yang terlihat pada gambar 4 tampak rapi, menarik dan jelas bagian-bagiannya. Di sebelah kiri bagian atas, tertulis materi prasyarat yaitu luas persegi, luas persegi panjang, luas segitiga dan luas jajargenjang. Di sebelah kanan materi prasyarat adalah tempat untuk menempelkan permasalahannya, yaitu trapesium yang merupakan representasi jendela rumah yang hendak dihitung luasnya. Pada bagian bawah dari kiri memanjang ke kanan adalah tempat untuk menempelkan dan menulis jawaban hasil pekerjaan peserta didik semua kelompok. Di sebelah atas pada bagian tengah adalah tempat untuk menuliskan kesimpulan pembelajaran, dan pada bagian atas paling kanan sebagai tempat untuk meletakkan tugas atau soal latihan.

\subsection{Kendala Pelaksanaan}

Pelaksanaan pembelajaran matematika dengan menerapkan model pembelajaran SPSBansho di SMPN 18 Tangerang berjalan lancar. Sejak awal, penulis sudah mempersiapkan dengan baik dan menginformasikan tentang rencana dan cara pelaksanaannya kepada seluruh peserta didik sebelum pembelajaran dilaksanakan. Tidak ada kendala selama pelaksanaan pembelajaran SPS-Bansho. Kendala yang ada hanya tidak ada papan tulis khusus di kelas yang bisa digunakan sebagai bansho, 
sehingga papan tulis di depan kelas yang digunakan sebagai bansho dan harus segera dihapus atau dibersihkan setelah jam pelajaran berakhir.

\subsection{Faktor Pendukung}

Beberapa faktor pendukung pelaksanaan best practice ini adalah: (1) kepala sekolah memberikan dukungan penuh kepada guru agar selalu kreatif dan inovatif dalam merancang dan melaksanakan pembelajaran di kelas; (2) pengaturan penggunaan papan tulis berbeda dari biasanya dan penulis menyediakan kertas warna-warni untuk menempelkan hasil kerja kelompok menjadikan tampilan bansho lebih menarik; (3) penulis mendokumentasikan bansho dan aktivitas belajar peserta didik melalui foto-foto menambah semangat peserta didik dalam mengikuti pembelajaran.

\subsection{Alternatif Pengembangan}

Berdasar faktor kendala dan pendukung pada pelaksanaan best practice ini, dapat ditempuh beberapa alternatif pengembangan sebagai berikut: (1) membuat refleksi hasil kegiatan sebagai dasar untuk melakukan penelitian lebih lanjut tentang model pembelajaran sps-bansho; (2) merancang pembelajaran sps-bansho pada pembelajaran berbasis dalam jaringan.

\section{Simpulan dan Saran}

Simpulan berdasar best practice yang telah dilaksanakan adalah sebagai berikut:

a. Penerapan model pembelajaran SPS-Bansho (Structured Problem Solving using Bansho) di SMPN 18 Tangerang dilakukan dengan 6 langkah SPS yaitu: mengecek materi prasyarat, menyajikan permasalahan matematika kontekstual, diskusi kelompok, diskusi kelas, kesimpulan dan refleksi serta latihan penguatan. Bansho sebagai pengorganisasian papan tulis memuat bagian-bagian terkait langkahlangkah SPS yaitu materi prasyarat, permasalahan dan tugas, hasil kerja peserta didik, kesimpulan dan refleksi serta latihan;

b. Penerapan model pembelajaran SPS-Bansho (Structured Problem Solving using Bansho) di SMPN 18 Tangerang memberi hasil atau dampak meningkatnya aktivitas belajar peserta didik yang dapat dilihat dari teramatinya semua indikator aktivitas belajar selama proses pembelajaran berlangsung yaitu: peserta didik menjadi lebih berani mengajukan pertanyaan pada waktu diskusi kelompok maupun diskusi kelas, mampu memberikan respon pendapat temannya dengan baik, mau berpartisipasi dalam kelompok, bersedia membantu teman dalam menyelesaikan tugas, mau mencoba melakukan presentasi di depan kelas, dan dapat dengan mudah menyusun rangkuman materi yang telah dipelajari.

Saran yang penulis kemukakan adalah: (1) Guru sebaiknya mengubah paradigma pembelajaran dari pembelajaran berpusat pada guru (teacher centered learning) menjadi pembelajaran berpusat pada peserta didik (student centered learning) sehingga 
peserta didik dapat terlibat lebih aktif dalam proses pembelajaran; (2) Dilakukan penelitian lebih lanjut tentang penerapan model pembelajaran SPS-Bansho (Structured Problem Solving using Bansho; (3)Guru sebaiknya lebih kreatif dan inovatif dalam menerapkan model pembelajaran; (4) Kepala Sekolah hendaknya selalu memberi kesempatan dan dukungan penuh kepada guru dalam melaksanakan inovasi pembelajaran dan melakukan pengembangan diri untuk menjadi guru profesional; (5) Sekolah sebaiknya melengkapi sarana/ prasarana untuk mendukung pembelajaran di kelas yang lebih baik.

\section{Daftar Pustaka}

Takahashi, A. (2006). Characteristics of Japanese Mathematics Lessons. Tsukuba Journal of Educational Study in Mathematics Volume https://www.criced.tsukuba.ac.jp/math/sympo_2006/takahashi.pdf . Dipetik 4 Oktober 2017.

Kajander, dkk. (2018). Teaching and Learning Secondary School Mathematics, Canadian Perspectives in an International Context. Springer International Publishing AG, part of Springer Nature.

Rahmat, B., Sudirman \& Muksar. M. (2018). Menumbuhkan Kreativitas Siswa Dengan Pembelajaran Menggunakan Bansho. Prosiding KNPMP III 2018. https://publikasiilmiah.ums.ac.id/bitstream/handle/11617/10178/Prosiding\%20KNPMP \%203\%202018-775p\%20ok_p013-775_p151-158.pdf?sequence=1\&isAllowed=y . Dipetik 11 Maret 2018.

Capacity Building Series, Bansho (Board Writing) Collective Knowledge Production in Ontario Mathematics Classroom. (February 2011). Secretariat Special Edition \#17. http://www.edu.gov.on.ca/eng/literacynumeracy/inspire/research/CBS_bansho.pdf Dipetik 13 April 2017.

Jonassen, D.H. (2000). Toward a Design Theory of Problem Solving. Educational Technology Research and Development, Volume 48 Pages 63-85. https://doi.org/10.1007/BF02300500 Dipetik 11 Maret 2018.

Djamarah \& Bahri, S. (2010). Guru dan Anak Didik dalam Interaksi Edukatif. Jakarta: Rineka Cipta.

Dale, E. (1969). Audiovisual Methods in Teaching. New York: Dryden Press.

Harto, D.K. (2012). Desain Pembelajaran Agama Islam untuk Sekolah dan Madrasah. Jakarta: PT. Raja Grafindo Persada.

Nugraha, H. (2018). Meningkatkan Kemampuan Berpikir Kreatif Matematis Siswa SMP Negeri Pagaden Melalui Model Pembelajaran Bansho. Prosiding Seminar Nasional Guru Dikdas Berprestasi. Jakarta: Direktorat Pembinaan Guru Pendidikan Dasar, Direktorat Guru dan Tenaga Kependidikan, Kementerian Pendidikan dan Kebudayaan.

KBBI Daring Edisi III, Hak Cipta Badan Pengembangan dan Pembinaan Bahasa (Pusat Bahasa). https://kbbi.web.id/aktivitas . Dipetik 13 Juni 2017.

Xie, K. (2006). Scaffolding Online Peer Collaboration to Enhance IIl-Structured Problem Solving With Computer-Based Cognitive Support. A Dissertation Submitted to The Graduate Faculty, University of Oklahoma. UMI Microform 3220375 ProQuest Information and Learning Company.

Leong, C. K., Teoh, B. T. \& Warabhorn, P. (2012). Introduction of the Bansho Plan to Primary School Mathematics Teachers: A Case Study. In A. L. White \& U. H. Cheah (Eds.), Transforming School Mathematics Education in the $21^{\text {st }}$ Century (pp. 33-44). Penang, Malaysia: SEAMEO RECSAM.

Leong, C. K., Teoh, B. T. \& Warabhorn, P. (2014, unpublised). Structured Problem Solving. The Learning Module in Customised Course for Indonesian Secondary Mathematics Educators. Penang, Malaysia: SEAMEO RECSAM.

Usman, M.U. (2017). Menjadi Guru Profesional. Bandung: Remaja Rosdakarya. 
Murwani \& Dwi, E. (2006). Peran Guru dalam Membangun Kesadaran Kritis Siswa. Jurnal Pendidikan Penabur No 06/Tahun V/Juni 2006. https://www.yumpu.com/id/document/view/29068853/peran-guru-dalam-membangunkesadaran-kritis-bpk-penabur . Dipetik 16 juni 2017.

Sardiman. (2011). Interaksi dan Motivasi Belajar Mengajar. Jakarta: PT Raja Grafindo Persada. Slameto. (2010). Belajar dan Faktor-Faktor yang Mempengaruhinya. Jakarta: Rineka Cipta. Usman \& Uzer,M. (2009). Menjadi Guru Profesional. Bandung: Remaja Rosdakarya.

Yoshida, M. (2002). Developing Effective Use of The Blackboard Study. From RBS Lesson Study Conference

2002. www.rbs.org/lesson_conference/2002/papers/yoshida_blackboard.shtm . Dipetik 13 Juni 2017. 